\title{
Diversity, composition and distribution of lichens along elevational gradients in the tropical mountain forest of Gunung Nuang, Selangor, Malaysia.
}

\author{
Azlan Abas \& Laily Din \\ Keywords: biodiversity, epiphytic lichen, Malaysia, montane forest, tropical lichen
}

\section{Abstract}

This study aims to explore how lichen diversity, composition and distribution vary with altitude, and environmental factors (temperature and relative humidity). The study was conducted in the forest of Gunung Nuang, Selangor at five sites (at different altitudes) which were chosen as sampling stations. Forty-four lichen species were identified. Their diversity, composition and distribution correlated significantly with the forest's altitude and environmental factors, increasing at higher altitudes. While Graphidaceae and Physciaceae species were present at all altitudes, the dominant species changed according to altitude: some species of Parmeliaceae were found only at higher altitudes (601-1 $493 \mathrm{~m}$ ), while C. xanthina and a few species from Physciaceae were present only at lower altitudes $(0-600 \mathrm{~m})$. These findings will provide additional information about the lichens of the tropical montane forest of Malaysia, enhancing knowledge on how to manage and sustain lichens in this type of forest.

\section{Profile}

Protected area

Gunung Nuang

Mountain range

Titiwangsa Main Range

of Peninsular Malaysia

\section{Introduction}

Lichen diversity and species composition are varied, depending on environmental conditions and type of ecosystem (Nimis et al. 2002). Lichens can be found growing from low-tide level to mountain summits, and from arctic and desert to tropical climate areas (Nash 2008; Abas et al. 2018). Lichens are unique dual-organisms (comprising fungus as mycobiont, and bluegreen algae or cyanobacteria as photobiont) which can show immediate responses to changes in environmental conditions (Abas et al. 2020). Some species are able to grow under harsh environmental conditions, while even slight changes in their environment cause others to perish. Lichens have three different growth forms: crustose, which grow attached to the substratum; foliose, which are leaf-like and loosely attached to the substratum; and fruticose, which are bush-like, and either hang, or grow upright on the substratum (Gaurav \& Upreti 2016). As well as their ecological roles, lichens with their metabolites have numerous biological properties, including antimicrobial, antiprotozoal, antiviral, anti-proliferative, anti-inflammatory, analgesic, antipyretic, anti-termite, antioxidant, cytotoxic, enzyme inhibitory, insecticidal, wound healing, and antitumor properties (Yilmaz et al. 2004; Kosanić et al. 2013; Rajan et al. 2016).

Malaysia, a tropical country, is known for its diverse and unique species of flora and fauna, but the study of lichen in Malaysia is far from complete (Abas \& Wang 2017). Most tropical lichens grow abundantly only at higher altitudes, such as in the montane forest, on hill summits, and in mountain ranges (Chongbang et al. 2018). The first lichen samples in Malaysia were recorded by Beccari (1904), who carried out a study on lichen in Sarawak. Galloway et al. (1994) prepared a bibliography of Malaysian lichenology comprfFising 90 entries, and an additional list comprising a further 192 entries (Galloway et al. 1997). Seven genera of lichens collected from Bario, Sarawak were identified by Din et al. (1998). Zakaria et al. (2010) reported on the morphology and chemical constituents of Cladia aggregata collected from Gunung Jerai, Kedah. The chemical components of a few specific samples of Heterodermia flabellata and Heterodermia leucomela from Gunung Jerai, Kedah and the Cameron Highlands, Pahang were described by Din et al. (2010). Lichens of North Eastern Langkawi and Gunung Machincang, Kedah were investigated by Zulkifly and Merican (2005), and lichen diversity and species composition (36 species were found) at Gunung Machincang were studied by Zulkifly et al. (2011). Urban lichen diversity and distribution in Kuala Lumpur have been analysed by Abas \& Awang (2017), and in Kota Kinabalu by Abas et al. (2020). Abas et al. (2019a) have reported 12 lichen species in Teluk Nipah, Pulau Pangkor, Perak as well.

Studies carried out in tropical forests have shown that environmental factors (e.g. temperature and humidity) and the forests' structure will vary significantly with altitude (Boonpeng et al. 2017). Other research has shown that lichen diversity, composition and distribution correlate significantly with, and are influenced by, environmental factors and the forest structure (Sulaiman et al. 2018; Abas et al. 2019b). Altitude has a strong connection with, and significant effects on, lichen diversity, composition and distribution. The results of the present study are consistent with the findings of Zulkifly et al. (2011), Upadhyay et al. (2018), and Abas et al. (2019a, b), who all concluded that lichen diversity, composition and distri- 


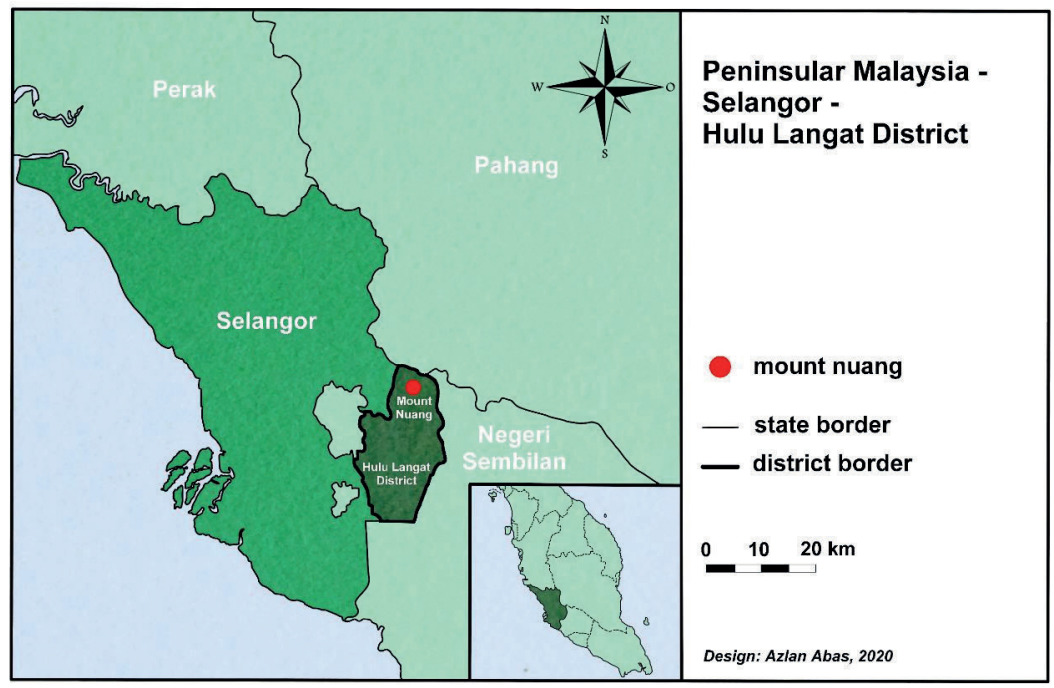

Figure 1 - Map of Gunung Nuang, Selangor

bution increase significantly, the higher the forest's altitude.

In Malaysia, there has been limited study of the specific lichens of tropical montane forest, and few studies are similar to our own. In this respect, Zulkifly et al. (2011) on Gunung Machincang, Langkawi, and Shahpuan et al. (2019) on foliicolous lichen in the Borneo Rainforest, Sabah, stand out. However, Shahpuan et al.'s study of composition and distribution is only very basic. Abas et al. (2019a, b) and Abas \& Awang. (2017) focused solely on lichen diversity in the lowland area, and more specifically on how lichen diversity was affected by air pollution and urbanization.

Information on lichen diversity, composition and distribution is still lacking for montane forests, especially in Malaysia. In addition, the uncontrolled development of land and recreational activity at Gunung Nuang have affected the diversity of the fauna. Hence, this study aims to identify and analyse lichen diversity, composition and distribution in Gunung Nuang, Selangor. It also aims to investigate the spatial distribution of lichens with regard to different elevations of Gunung Nuang. It could also raise awareness of how environmental changes at Gunung Nuang have affected the diversity of the mountain's flora and fauna.

\section{Study area}

Gunung Nuang is located in Hulu Langat District, Selangor. Rising to 1493 m (4898 feet), Gunung Nuang is the highest mountain in the state of Selangor, while part of its peak lies in the Titiwangsa Main
Range of Peninsular Malaysia. The peak also borders on Pahang state and is close to the Pahang-SelangorNegeri-Sembilan border tripoint. Gunung Nuang is covered by an extensive montane forest, making it an attractive tourist destination for hiking and mountain climbing. There are three hiking routes to the peak, all of them built by the Malaysian Department of Wildlife and National Parks. Two of them start in Selangor - one at Kuala Pangsun in Hulu Langat, the other at Kampung Kemensah in Gombak. The third route originates in Bukit Tinggi. The Genting Highlands in Pahang are visible (especially at night) from the peak of Gunung Nuang, which is accessible from the Kuala Pangsun route. The climb involves a two-hour hike on a very steep track, then an optional stop at Camp Lolo, followed by a four-hour trek to the start of the climb proper and a six-hour push to the summit. Gunung Nuang is vulnerable to global climate change. In 1990, Gunung Nuang's lowest recorded temperature was $14^{\circ} \mathrm{C}$, but in 2015 it had increased to $18^{\circ} \mathrm{C}$. This temperature increase is due also to the development, since 1995, of the nearby Semenyih Dam, and the numerous recreational activities conducted in the region since 1997, with the opening of its famous trail (Forest Department Peninsular Malaysia 2019).

The study was conducted at five sites along the hiking trail of Gunung Nuang, Selangor, between the Kuala Pangsun entrance and Gunung Nuang's peak (Figure 1). According to Zulkifly et al. (2011), the ecological stands of tropical forests vary every 200 $400 \mathrm{~m}$. In order to observe the change in lichen diversity, distribution and composition along elevational

Table 1 - Environmental factors for each sampling site. Source: Malaysia Meteorological Department (2019).

\begin{tabular}{|l|l|r|r|r|}
\hline Site & Coordinates & Altitude [m] & Relative Humidity [\%] & Temperature [ ${ }^{\circ}$ ] \\
\hline 1 & $3.216894 \mathrm{~N}, 101.883468 \mathrm{E}$ & $0-299$ & 80.7 & 32.5 \\
\hline 2 & $3.235284 \mathrm{~N}, 101.901734 \mathrm{E}$ & $300-599$ & 81.1 & 31.8 \\
\hline 3 & $3.246242 \mathrm{~N}, 101.905081 \mathrm{E}$ & $600-899$ & 82.5 & 27.1 \\
\hline 4 & $3.256777 \mathrm{~N}, 101.905365 \mathrm{E}$ & $900-1199$ & 87.9 & 23.2 \\
\hline 5 & $3.263782 \mathrm{~N}, 101.903943 \mathrm{E}$ & $1200-1493$ & 90.3 & 21.3 \\
\hline
\end{tabular}




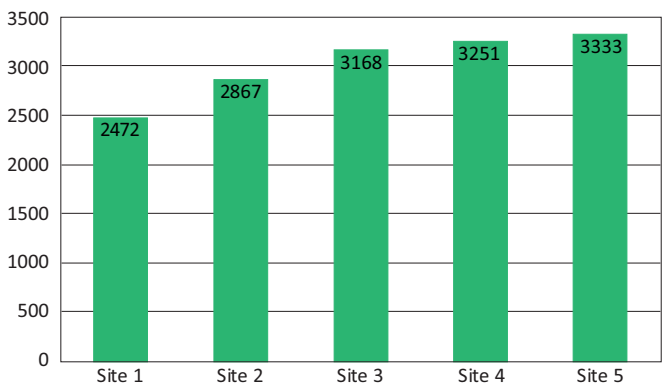

Figure 2 - The Shannon-Weiner Index.

gradients, therefore, this study used mostly $300 \mathrm{~m}$ intervals in selecting the study sites: Site $1(0-300 \mathrm{~m}$ a.s.l.), Site 2 (300-599 $\mathrm{m}$ a.s.l.), Site 3 (600-999 m a.s.l.), Site 4 (1 000-1299 m a.s.l), and Site 5 (1300-1 493 m a.s.l.). The study area has a warm tropical climate, with annual average minimum and maximum temperatures of $19^{\circ} \mathrm{C}$ and $33^{\circ} \mathrm{C}$ respectively; monthly rainfall can be as low as zero in January and as high as $342 \mathrm{~mm}$ in December, when there is heavy monsoon rain, which starts in November (Malaysian Meteorological Service 2018). The study sites included protected tropical rainforest reserves; diverse species and a variety of forest structures are distributed throughout the region. In addition, Gunung Nuang is also a protected area (Category VI: Protected Area with sustainable use of natural resources) under the management of Selangor State Foresty Department.

\section{Method}

\section{Sampling procedures and data analysis}

The sampling of lichens was carried out at five sites along the trail that leads to the summit of Gunung Nuang. The environmental conditions of the study sites, such as temperature, humidity and altitude, were recorded (see Table 1). The sampling plot at each site was determined using a stratified random sampling method for an area of $20 \mathrm{~m} \times 20 \mathrm{~m}$, or $400 \mathrm{~m}^{2}$, the size being based on a preliminary site investigation, as recommended by Khaien et al. (2018). Only epiphytic lichens were collected; the coordinates of the lichens were noted.

The lichen samples were taken to the Algae Lab at the National University of Malaysia (UKM) for identification by observing their morphological traits under stereoscopic and optical microscopes. The external characteristics of the lichens, such as the lobes, thallus, pycnidia, rhizines, ciliates and apothecia, were analysed thoroughly (Nimis et al. 2002). A spot test was used to determine the presence of acid (the lichen's secondary metabolites) in the medulla and cortex (Sipman 2009). All the data acquired from both techniques (morphological observation and spot test) were recorded and incorporated into the Lichen Herbarium of UKM, Malaysia.

Lichen species richness and composition were calculated and presented as percentages of the total

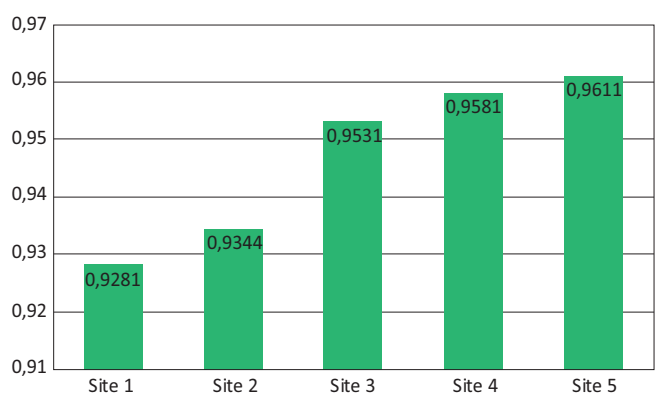

Figure 3 - Simpson's Diversity Index.

number of samples, using a cluster bar chart. Next, an independent t-test was used to examine the difference in species composition between lower- and higher-frequency species (Sevgi et al. 2019). Species diversity was analysed using the two most common diversity indices - the Shannon-Weiner Index and Simpson's Diversity Index. The Shannon-Weiner Index is more useful in identifying rare species; Simpson's Diversity Index is more useful and effective for more abundant species (Simpson 1949; Barnes et al. 1998). The Similarity Index was used to investigate which lichens were endemic to certain sites (according to altitudinal difference). Correspondence Analysis (CA) was used to illustrate the variation in the species distribution and abundance along the elevational gradient in Gunung Nuang, Selangor (Benzecri 1973). All the statistical analyses were performed using the $\mathrm{R}$ program version 4.0, and SPSS statistical software version 23.0.

\section{Results}

\section{Lichen species diversity}

A total of 44 lichen species belonging to 11 families were collected from Gunung Nuang, Selangor. The highest number of species collected was at site 5 (35 species), followed by Site 4 (32), Site 3 (31), Site 2 (25), and lastly Site 1 (21).

The diversity of lichen species was determined using the Shannon-Weiner Index (Figure 2) and Simpson's Diversity Index (Figure 3). The diversity varied significantly among sampling sites (ANOVA, $\mathrm{p}<0.05$ ), with Site 5 having the greatest diversity, showing that lichen species diversity tends to increase with increased altitude.

\section{Lichen species composition and distribution}

The lichen species composition and distribution varied within and among sampling sites. Bar charts were produced to analyse lichen distribution and composition for each of the sampling sites (Figure 4: Site 1; Figure 5: Site 2; Figure 6: Site 3; Figure 7: Site 4; Figure 8: Site 5). Lichen species from Graphidaceae, Physiaceae, Pyrenulaceae and Chryptotaceae were found at all sampling sites, but the particular species found varied from site to site. Some species were found at only one site - for example, Chrysothrix xanthina at Site 1, and Parmotrema mellissii and Parmelia sulcata at Site 5. 


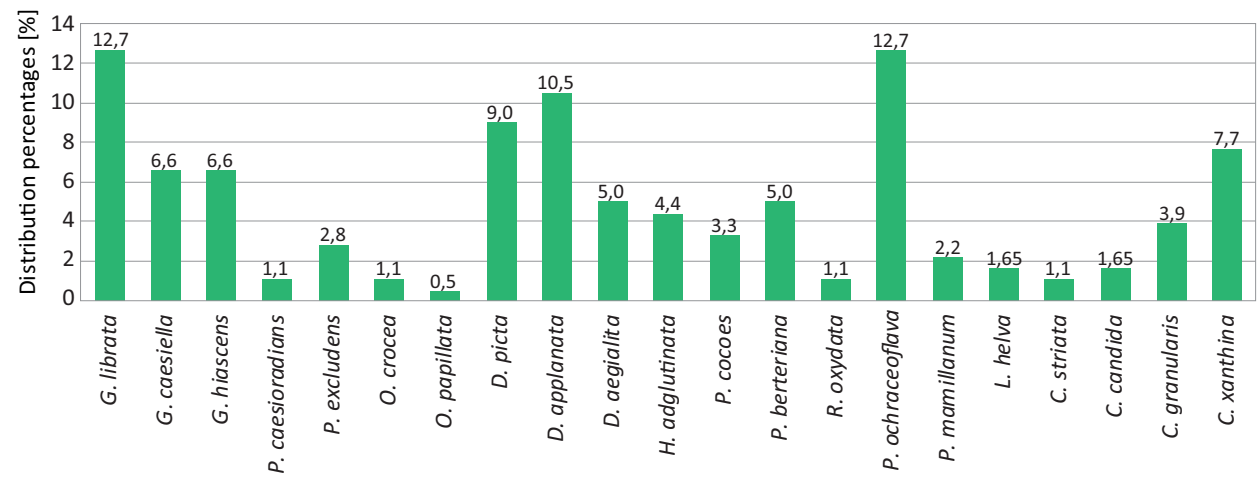

Figure 4-Distribution of lichen species for Site $1(0-300 m)$.

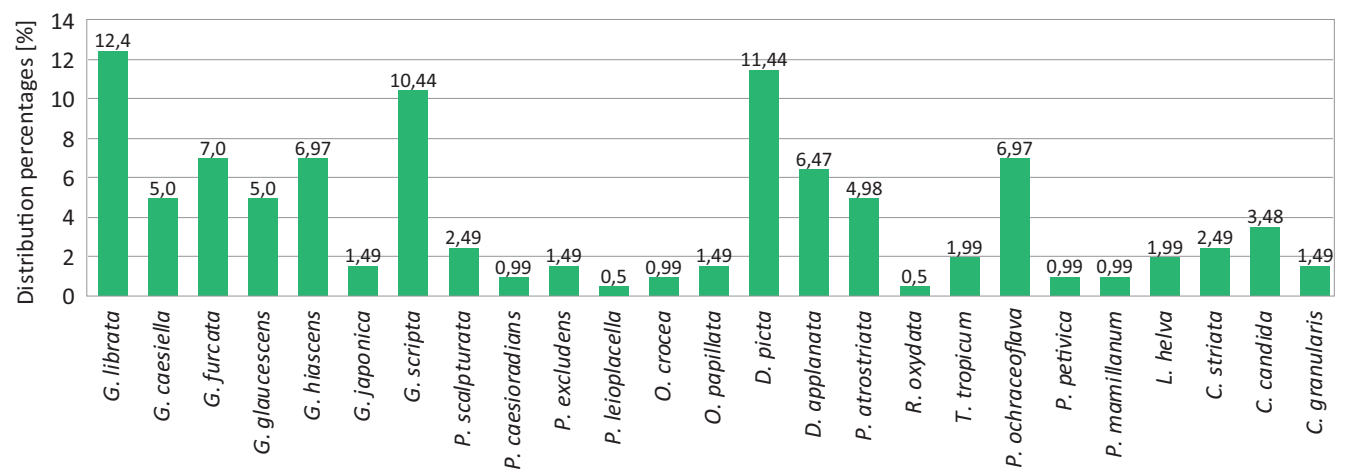

Figure 5-Distribution of lichen species for Site 2 (301-600m).

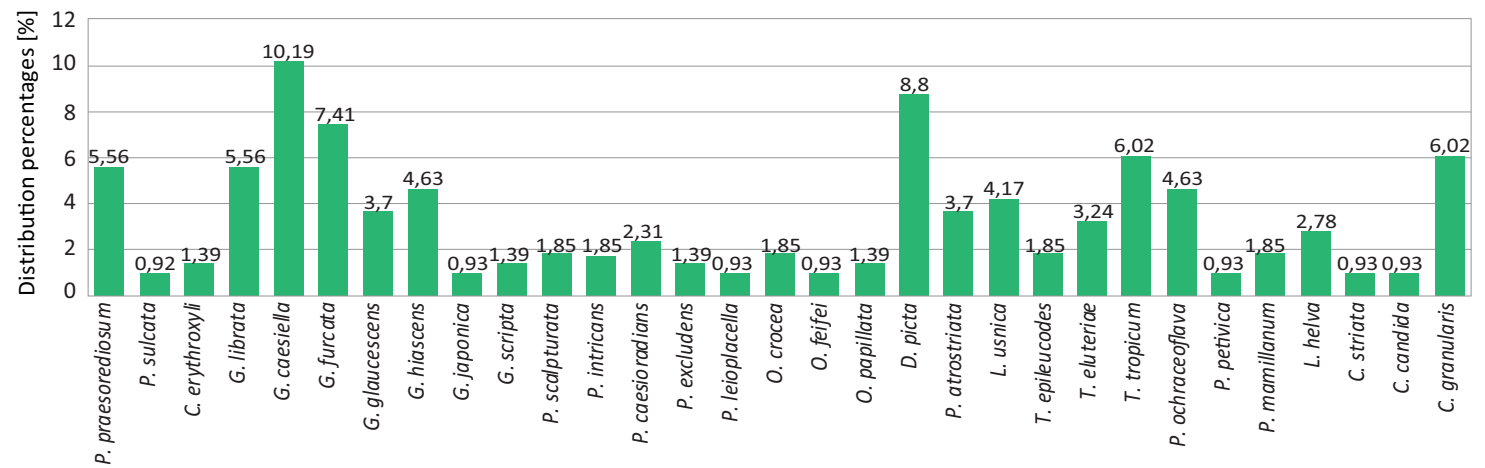

Figure 6-Distribution of lichen species for Site 3 (601-900m).

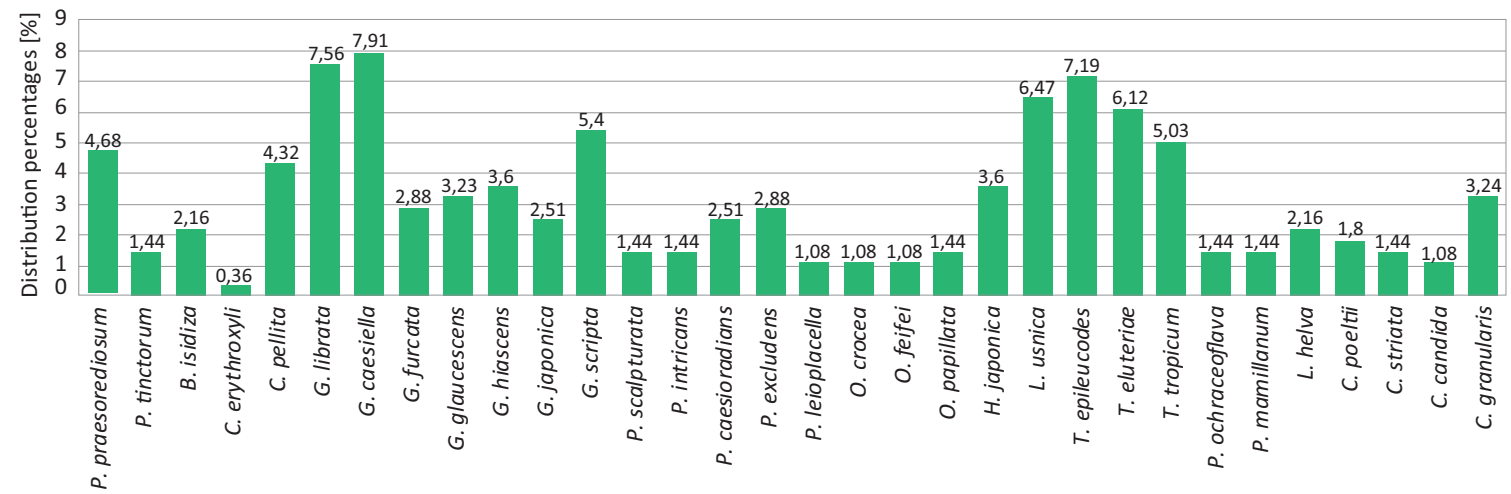

Figure 7 - Distribution of lichen species for Site 4 (901-1200m).

As shown in Figure 4, there are two dominant species at Site 1, namely Graphis librata and Pyrenula ochraceoflava (both $12.7 \%$ of samples). These are followed by Dirinaria applanata (10.5\%), Dirinaria picta $(9.0 \%)$, Chrysothrix xanthina (7.7\%), Graphis casiella (6.6\%), Gra- phis biascens (6.6\%), Dirinaria aegialita (5.0\%), and Pyxine berteriana (5.0\%). Other species - Phaegraphis caesioradians $(1.1 \%)$, Rinodina oxydata $(1.1 \%)$, Ocellularia papililata $(0.5 \%)$ - had percentages significantly below $5 \%$. The majority of the samples from Site 1 were from the 


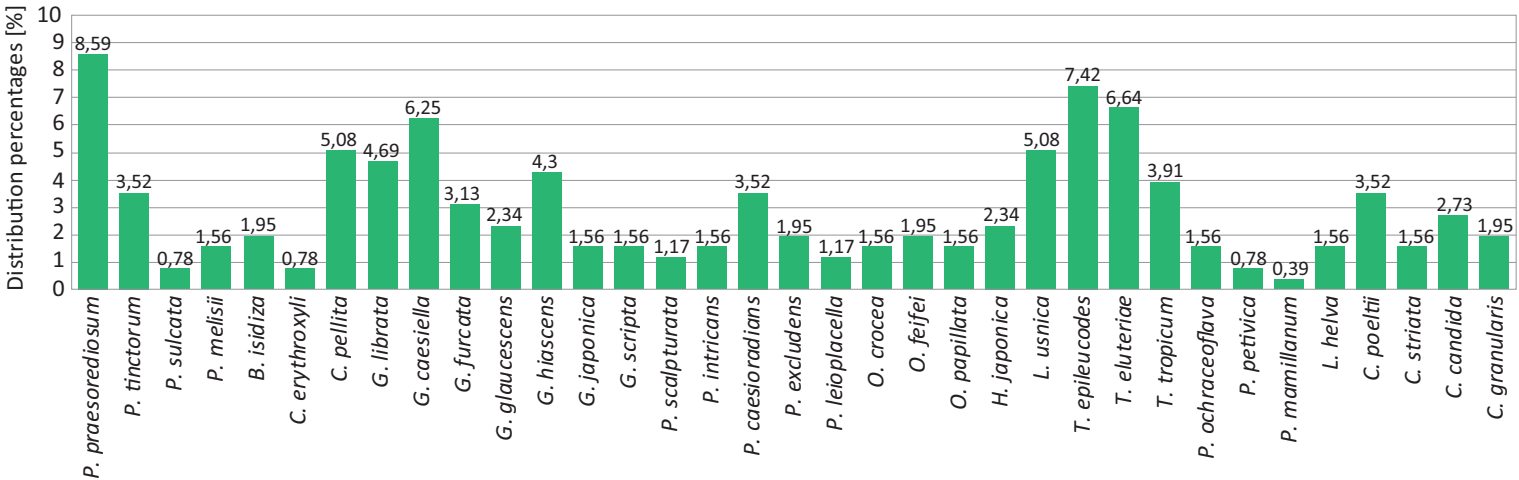

Figure 8-Distribution of lichen species for Site 5 (1 201-1493 m).

Table 2 - The Similarity Index data for each sampling site

\begin{tabular}{|l|l|l|l|l|l|}
\hline & Site 1 & Site 2 & Site 3 & Site 4 & Site 5 \\
\hline Site 1 & & 0.570681 & 0.433249 & 0.331155 & 0.28833 \\
\hline Site 2 & 0.570681 & & 0.623501 & 0.480167 & 0.424508 \\
\hline Site 3 & 0.433249 & 0.623501 & & 0.663968 & 0.631356 \\
\hline Site 4 & 0.331155 & 0.480167 & 0.663968 & & 0.816479 \\
\hline Site 5 & 0.28833 & 0.424508 & 0.631356 & 0.816479 & \\
\hline
\end{tabular}

crustose group, and only Chrysothrix xanthina was from the leprose group. Graphidaceae and Physciacea are the dominant lichen families for Site 1, both families being represented there by at least five species.

At Site 2, as Figure 5 shows, the most dominant species was again Graphis librata, with $12.4 \%$. This was followed by Dirinari picta (11.44\%), Graphis scripta $(10.44 \%)$, Graphis furcata $(7.0 \%)$, Graphis biascens (6.97\%), Pyrenula ochraceoflava (6.97\%), Dirinaria applanata (6.47\%), Graphis caesiella (5.0\%), and Graphis glaucescens $(5.0 \%)$. The lowest figures for Site 2 were for Phaeographis leioplacella $(0.5 \%)$ and Pyrenula petivica $(0.99 \%)$. The majority of the species collected at the site were from the crustose lichen group. Graphidaceae and Physciaceae are again the most dominant families here, represented by at least 5 species each.

Figure 6 shows the composition distribution of lichen species for Site 3. The most dominant species was Graphis caesiella, with $10.19 \%$, followed by Dirinaria picta $(8.8 \%)$, Graphis furcata $(7.41 \%)$, Trypethelium tropicum (6.02\%), Cryptothesia granularis (6.02\%), and Graphis librata and Pramotrema praesorediosum (both 5.56\%). Coccocarpia erythroxyli and Cryptothesia striata were among the lichen species that scored less than $5 \%$. The majority of the lichens found here belong to the crustose group, but foliose lichens such as Coccocarpia erythroxyli and Pramotrema praesorediosum were also collected at this site. The most dominant family was Graphidaceae (12 species found); 2 species of Parmeliaceae and 1 of Coccocarpiaceae were also found at Site 3.

Site 4 recorded 32 lichen species (see Figure 7). The most dominant species here was Graphis caesiella (7.81\%), followed by Graphis librata (7.58\%), Trypethelium epilencodes (7.19\%), Lepraria usnica (6.47\%), Graphis scripta (6.12\%), and Trypethelium tropicum (5.4\%). Coc- cocarpia erythroxyli and Parmotrema tinctorum both accounted for less than $5 \%$ of samples. Crustose lichens dominated, but the foliose group was also represented by several species. Graphidaceae was the dominant lichen family at Site 4; other species belonged to the Collemataceae family.

Figure 8 shows the lichen species composition and distribution for Site 5 . The most dominant species was Parmotrema praesorediosum (8.59\%), followed by Trypethelium epileucodes (7.42\%), Trypethelium eluteriae (6.64\%), Graphis caesiella (6.25\%), Coccocarpia pellita and Lepraria usnica (5.08\%). Bulbothrix isidiza and Parmotrema mellissii each accounted for less than $5 \%$ of samples. Both crustose and foliose lichen groups were found abundantly. Graphidaceae was the dominant lichen family, but Parmeliaceae were also well represented.

\section{The Similarity Index for the sampling sites}

The Similarity Index (Table 2) showed how the sites differed according to the presence or absence and abundance of species. The similarity between Sites 4 and 5 was higher than for Sites 3 and 4, or for Sites 3 and 5. Sites 1 and 5 have the lowest similarity (less than $30 \%$ ).

The sampling sites can be classified into two main groups, based on their ecological distances. A dendrogram (Figure 9) shows that the ecological distances between Sites 3 and 5, and between Sites 1 and 2 were the closest. Thus altitudes of 601-1493 m can be considered as one group, with altitudes of $0-600 \mathrm{~m}$ falling into a separate group.

Effects of altitude on lichen species diversity, composition and distribution

Lichen diversity, composition and distribution varied according to altitude, and environmental conditions such as humidity and temperature. The differences between lichen diversity and abundance correlated significantly with the location's altitude, temperature and humidity. Altitude and environmental factors had a stronger effect on species distribution from 0 to $1493 \mathrm{~m}$. Correspondence analysis (CA) showed that there was a very clear correlation between species diversity and distribution on the one hand, and sam- 


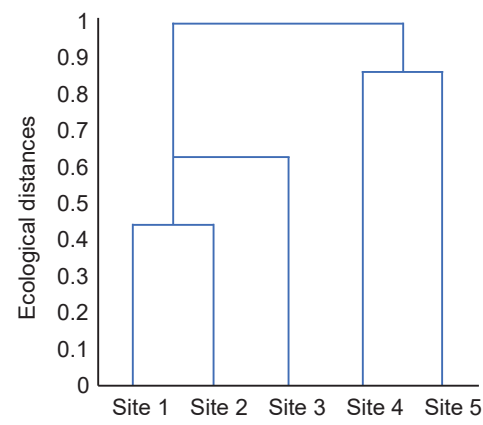

Figure 9 - Dendrogram showing the similarity of species abundance for all sites.

pling site altitude on the other (Figure 10). The first and second axes of CA show more than $60 \%$ of the total fitted variation. The weighted average scores for lichen diversity at different altitudes vary greatly, with the abundance and distribution of lichens spreading into different quarters of the ordination graph. Where a sampling point in the graph is located close to a particular species, that species is expected to be highly abundant and frequent at the sampling point. For example, Chrysothrix xanthina, Pyxine cocoes, Pyxine berteriana, Hyperphyscia adglutinata and Dirinaria aegialita are located close to Site 1, which means that these species are abundant only at Site 1; a higher altitude than that of Site 1 was not an appropriate condition and habitat for this species. It should be noted that a small vector angle between species corresponds to a strongly positive association, and a $180^{\circ}$ vector angle between species corresponds to a negative correlation.

\section{Discussion}

Lichen species that belong to the Graphidaceae and Physciaceae families were present at all forest altitudes (Sites 1-5), but the specific species that emerged were different. For example, among the Graphidaceae Phaeographis intricans and Graphis japonica were present only at 601-1 $493 \mathrm{~m}$ (Sites 3-5), while Heterodermia japonica, of the Physciaceae family, was found only at 901$1493 \mathrm{~m}$ (Sites 4 and 5). On the other hand, Dirinaria aegialita, Pyxine cocoes, Pyxine berteriana and Hyperphyscia adglutinata (all Physciaceae) were present at $0-300 \mathrm{~m}$ (Site 1) only. Similarly, Chrysothrix xanthina (a leprose lichen) was found only at $0-300 \mathrm{~m}$. These differences can be explained by the differing environmental factors between altitudes. For example, altitudes of 0-300 $\mathrm{m}$ are lowland areas, which are vulnerable to air pollution and human activities. Anthropogenic activities lead to increased nitrogen and sulphur in the atmosphere, and only acidophile and nitrophile types of lichens can survive in high concentrations of these elements. Parmeliaceae, Coccocarpiaceae and Collemataceae species were present only at high altitudes (601-1 493 m; Sites 3-5). These three families are foliose-type lichens, which only grow at low temperatures in areas of high humidity. A study by Sipman (2009)

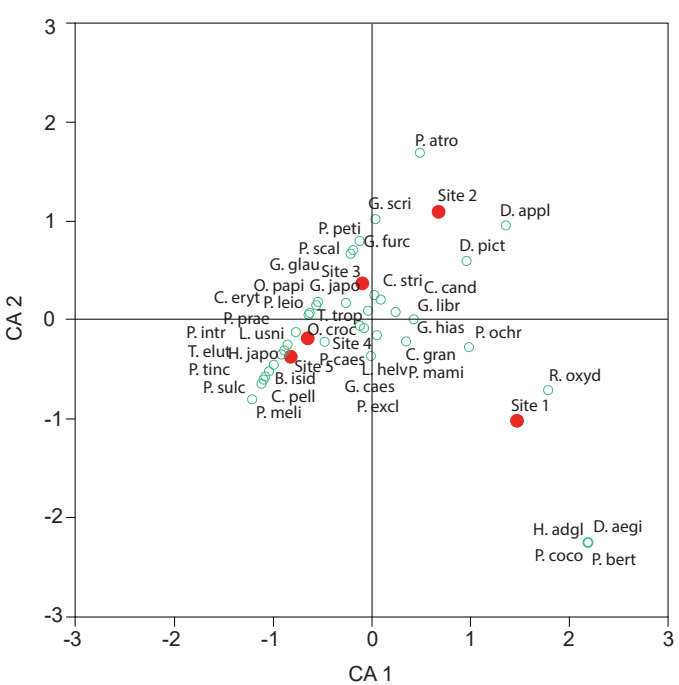

Figure 10 - CA showing the relationship between species distribution and elevation for each sampling site.

concluded that foliose-type lichens can grow abundantly at higher altitudes in regions with tropical climates. In addition, most of the Parmeliaceae, such as Parmotrema tinctorum, Parmotrema mellissii and Coccocarpia pellita, are highly sensitive to air pollution, which is why these species are found commonly only in pristine and remote forests.

Species distribution correlated strongly with climatic conditions, especially temperature and relative humidity. Furthermore, the abundance of species has been proved to vary according to altitudinal zone. Our study found that Chrysothrix xanthina, Pyxine cocoes, Pyxine berteriana, Dirinaria aegialita, Rinodina oxydata and Hyperphyscia adglutinata grew exclusively at altitudes of $0-300 \mathrm{~m}$, with average coverage of $33 \%$. Dirinaria picta, Dirinaria applanata and Physcia atrostriata grew in abundance at 301-600 m, where they were 55\% more abundant than at lower altitudes. Graphis japonica and Cryptothesia striata were found exclusively at 601$900 \mathrm{~m}$, with average coverage of $44 \%$ for both species. Several Parmeliaceae, Coccocarpiacea and Collemataceae species, such as Parmotrema tinctorum, Parmotrema praesorediosum, Parmotrema mellissii, Bulbothrix isidiza, Parmelia sulcata, Coccocarpia pellita, Coccocarpia erythroxyli and Collema poeltii, were found thriving at $901 \mathrm{~m}$ and above, with average coverage of $53 \%$.

Our study found that some lichen species, such as Cryptothesia granularis, Ocellularia crocea, Graphis librata and Graphis caesiella, were present at almost all altitudes. This is in agreement with the findings of Zulkifly et al. (2011), who found that some Graphidaceae and Cryptothesiacea species were common in montane forest at all altitudes. This may be because of the ability of this lichen family to adapt, making it less vulnerable to its surroundings even if there are changes in the quality of the environment (Abas et al. 2018).

Geographically, tropical forests are located in equatorial regions (Khamis \& Nizam 2013). This gives the forests a unique structure which makes them suitable 
habitats for thousands of endemic bryophyte and lichen species (Sevgi et al. 2019). The number of lichen species found in Gunung Nuang, Selangor (44 species) was significantly higher than that found for the montane forest at Gunung Machincang, Langkawi (33 species) (Zulkifly et al. 2011). Somewhat fewer lichen species again were found in Araucaria forest of Southern Brazil (27 species) (Kaffer et al. 2009). The varying numbers of lichen species present in different areas may be due to physical geographical boundaries and climatic variation.

\section{Conclusion}

In this study, we found that lichen species diversity, composition and distribution in Gunung Nuang, Selangor increase with the montane forest's altitude. The dominant lichen species also varied according to altitude. Although the diversity does not change significantly between 0 and $600 \mathrm{~m}$ (Sites 1 and 2), at altitudes of 601-1 $493 \mathrm{~m}$ (Sites 3-5) it did do so, with the presence here of a few endangered lichen species. Given the link between altitudinal gradient and environmental factors (lower temperature and higher humidity at higher altitudes) which are essential for lichen growth and forest productivity, our study's findings are consistent with earlier studies that show a positive correlation between lichen species and forest altitude. The study also verified that some lichen species present in Gunung Nuang, Selangor, such as Parmotrema mellissii, Collema poeltti and Coccocarpia pellita, are threatened by the loss of forest and by human activities. These species need to be protected and managed to ensure their survival in this tropical montane forest.

Our findings add to knowledge of Malaysia's lichens, and have implications for phytogeography and ecology, especially montane forest ecology, giving insight into how elevation gradient and variation of environmental factors can determine the diversity, composition and distribution of lichens. The results of our study will thus be of use in determining appropriate management techniques in tropical regions more widely.

\section{Acknowledgments}

This study was conducted with the financial support of GUP-2018-032 research grant provided by the Universiti Kebangsaan Malaysia (UKM). We are grateful to everyone who helped with the field survey. We would like to thank all anonymous reviewers for their constructive comments.

\section{References}

Abas, A. \& Awang, A. 2015: Penentuan tahap pencemaran udara di Malaysia Menggunakan pendekatan penunjuk bio (Liken): Kajian kes Bandar Baru Bangi. Geografia: Malaysian Journal of Society and Space. 11 (9): 67-74. [In Malay]
Abas, A. \& A. Awang 2017. Air pollution assessment using lichen biodiversity index (LBI) in Kuala Lumpur, Malaysia. Pollution Research 36(2): 242-249.

Abas, A., A. Awang \& K. Aiyub 2020. Analysis of heavy metal concentration using transplanted lichen Usnea misaminensis at Kota Kinabalu, Sabah (Malaysia). Applied Ecology and Environmental Research 18 (1): 1175-1182. Doi: 10.15666/aeer/1801_11751182

Abas, A., A. Awang \& L. Din 2018. Liken: Khazanah Hidupan Terasing. Bangi: Penerbit Universiti Kebangsaan Malaysia. [In Malay]

Abas, A., R.M. Khalid, A.R. Rosandy \& N. Sulaiman 2019a. Lichens of Pulau Pangkor, Perak. The Malaysian Forester 82(1): 59-66.

Abas, A., M.S. Nizam \& M.W. Aqiff 2016. Elevated $\mathrm{CO}_{2}$ effects on lichen frequencies and diversity distribution in free-air $\mathrm{CO}_{2}$ enrichment (FACE) station. Journal of Environmental Protection 7: 1192-1997.

Abas, A., N. Sulaiman, N.R. Adnan, S.A. Aziz \& W.N.S.W. Nawang 2019b. Using lichen (Dirinaria sp.) as bio-indicator for airborne heavy metal at selected industrial areas in Malaysia. EnvironmentAsia 12(3): 85-90.

Barnes B.V, D.R. Zak, S.R. Denton \& S.H. Spurr 1998. Forest ecology (4 $4^{\text {th }}$ ed.).

Beccari, O. 1904. Wanderings in the Great Forest of Borneo: London.

Benzecri, J.-P. 1973. L'analyse des données. 2 L'analyse des correspondances. Paris. [In French]

Boonpeng, C., W. Polyiam, C. Sriviboon, D. Sangiamdee, S. Watthana, P.L. Nimis \& K. Boonpragob 2017. Airborne trace elements near petrochemical industry complex in Thailand assessed by the lichen Parmotrema tinctorum (despr. Ex Nyl.) Hale. Environmental Science and Pollution Research 24(13): 1-8.

Carreras, H.A. \& M.L. Pignata 2002. Biomonitoring of heavy metals and air quality in Cordoba City, Argentina, using transplant lichens. Enviromental Pollution 117: 77-87.

Chongbang, T.B., C. Keller, M. Nobis, C. Scheidegger \& C.B. Baniya 2018. From natural forest to cultivated land: Lichen species diversity along landuse gradients in Kanchenjunga, Eastern Nepal. eco. mont - Journal on Protected Mountain Areas Research and Management 10(1): 46-60. Doi: 10.1553/eco.mont-101s46

Cioffi, M. 2009. Air quality monitoring with the lichen biodiversity index (LBI) in the district of Faenza (Italy). EQA-Environmental Quality 1: 1-6.

Din, L.B., Z. Zakaria, v Samsudin \& J.A. Elix 2010. Chemical profile of compounds from lichens of Bukit Larut Peninsular Malaysia. Sains Malaysiana 39(6): 901908.

Forestry Department Peninsular Malaysia. $15^{\text {th }}$ September 2019. Gunung Nuang, Selangor. Available at: https://www.forestry.gov.my/my/selangor/hutanlipur-gunung-nuang

Galloway, D.J., L.B. Din \& A. Latiff 1997. A bibliography of Malaysian lichenology. Malaysian Applied Biology 26(1): 93-99. 
Galloway, D.J., M.W. Samsudin \& A. Latiff 1994. A bibliography of Malaysian lichenology. Malaysian Applied Biology 22: 215-221.

Gaurav K.M. \& D.K. Upreti 2016. Diversity and distribution of macro-lichen in Kumaun Himalaya, Uttarakhand. International Journal of Advanced Research 4(2): 912-925.

Kaffer, M.I., G. Ganade \& M.P. Marcelli 2009. Lichen diversity and composition in Araucaria forests and tree in southern Brazil. Biodiversity Conservation 18: 3543-3561.

Khamis, S. \& M.S. Nizam 2013. Distribution of Litsea complex (Lauraceae) and their association with soil properties in different forest types of Peninsular Malaysia. AIP Conference Proceedings 1571(363). Doi: $10.1063 / 1.4858684$

Khan, M., A.N. Khalid \& H.T. Lumbsch 2018. A New Species of Lecidea (Lecanorales, Ascomycota) from Pakistan. MycoKeys 38: 25-34. Doi: 10.3897/ mycokeys.38.26960

Kosanic, M., B. Rankovic \& T. Stanojkovic 2013. Investigation of selected serbian lichens for antioxidant, antimicrobial and anticancer properties. The Journal of Animal and Plant Sciences 23(6): 1628-1633.

Nash, T.H. 2008. Lichen Biology. $4^{\text {th }}$ edition. Cambridge, United Kingdom.

Nimis, P.L., C. Scheidegger \& P.A. Wolseley 2002. Monitoring with Lichens. Netherlands.

Protano, C., M. Owczarek, A. Antonucci, M. Guidotti \& M. Vitali 2017. Assessing indoor air quality of school environments: transplanted lichen Pseudovernia furfuracea as a new tool for biomonitoring and bioaccumulation. Environmental Monitoring Assessment 189: 358.

Rajan, V.P., S. Gunasekaran, S. Ramanathan, V. Murugaiyah, M. Samsudin \& L. Din 2016. Biological activities of 4 Parmotrema species of Malaysian origin and their chemical constituents. Journal of Applied Pharmacentical Science 6(8): 36-43.

Samsudin, M.W., H. Azahar, A. Abas \& Z. Zakaria 2013a. Determination of Heavy Metals and Polycyclic Aromatic Hydrocarbon (UKM) Contents Using Lichen Dirinaria picta in University Kebangsaan Malaysia. Journal of Environmental Protection 4: 760-765.

Samsudin, M.W., R. Daik, A. Abas, T.S.M. Meerah \& L. Halim 2013b. Environmental learning workshop: Lichen as biological indicator of air quality and impact on secondary student's performance. International Education Studies 6(6): 28-34.

Sevgi, E., O.Y. Yılmaz, G. Çobanoğlu Özyiğitoğlu, H.B. Tecimen \& O. Sevgi 2019. Factors Influencing Epiphytic Lichen Species Distribution in a Managed Mediterranean Pinus nigra Arnold Forest. Diversity 11(4): 59. Doi: $10.3390 / \mathrm{d} 11040059$

Shahpuan, M.S., L.A. Laneng, K.C. Looi, Y. Inaguma \& C.S. Vairappan 2019. New dataset of foliicolous lichens on leaves of five major species of Dipterocarpaceae in INIKEA forest rehabilitation plot of Borneo. Data in Brief 27: 104422. Doi: 10.1016/j. dib.2019.104422
Shukla, V., D.K. Upreti, D.K. Patel \& M. Yunus 2012. Lichens reveals air PAH fractionation in the Himalaya. Environmental Chemistry Letters 11: 19-23

Simpson, E.H. 1949. Measurement of diversity. $\mathrm{Na}$ ture 163: 688. Doi: 10.1038/163688a0

Sipman, H.J.M. 1989. Lichen Zonation in the Parque Los Nevados Transect. Studies on Tropical Andean Ecosystems 3: 461-483.

Sipman, H.J.M. 1993. Lichens from Mount Kinabalu. Tropical Bryology 8: 281-314.

Sipman, H. 2009. Tropical urban lichens: observations from Singapore. Blumea 54: 297-299.

Sulaiman, N., S.F.F. Mohd Fuzy, S.I.N. Abdul Muis, N. Sulaiman \& B.S. Ismail 2018. Use of lichens as bioindicators for determining atmospheric heavy metals concentration in Malaysia. Pakistan Journal of Botany 50(1): 421-428.

Svoboda, D., O. Peksa \& J. Vesela 2011. Analysis of the species composition of epiphytic lichens in Central European oak forests. Preslia 83: 129-144.

Upadhyay, S., A.K. Jugran, Y. Joshi, R. Suyal \& R.S. Rawal 2018. Ecological variables influencing the diversity and distribution of macrolichens colonizing Quercus leucotrichophora in Uttarakhand forest. Journal of Mountain Science 15(2): 307-318. Doi: 10.1007/s11629017-4397-9

Yilmaz, M, A.Ö. Türk, T. Tay \& M. Kıvanç 2004. The antimicrobial activity of extracts of the lichen Cladonia foliacea and its (-) - Usnic Acid, Atranorin and Fumarprotocetraric Acid Constituents. Zeitschrift für Naturforschung C 59(3-4): 249-254.

Zakaria, Z., L.B. Din, A. Latiff \& J.A. Elix 2000. Notes on the Morphology and Chemical Constituents of the Lichen, Cladia aggregata (Sw.) Nyl. in Peninsular Malaysia. Malayan Nature Journal 54: 27-30.

Zulkifly, S. \& A.F. Merican 2005. Some lichens of north eastern Langkawi and Gunung Machincang, Langkawi Islands. Malaysian Journal of Science 24: 103110.

Zulkifly, S., Y.S. Kim, M. Abdul Majid \& A.F. Merican 2011. Distribution of Lichen Flora at Different Altitudes of Gunung Machincang, Langkawi Islands, Malaysia. Sains Malaysiana 40(11): 1201-1208.

\section{Authors}

Azlan Abas - Corresponding author

Centre for Research in Development, Social and Environment, Faculty of Social Sciences and Humanities, Universiti Kebangsaan Malaysia, 43600 UKM Bangi, Selangor, Malaysia. E-mail: azlanabas@ukm. edu.my

\section{Laily Din}

School of Chemical Sciences and Food Technology, Faculty of Science and Technology, Universiti Kebangsaan Malaysia, 43600 UKM Bangi, Selangor, Malaysia. 